\title{
PENGARUH LKS DENGAN STRATEGI INKUIRI TERBIMBING BERBASIS PENALARAN TERHADAP KETERAMPILAN PENGAMBILAN KEPUTUSAN SISWA SMA PADA MATERI ENERGI TERBARUKAN
}

EFFECT OF LKS WITH INTERESTED INKUIRI STRATEGY BASED ON REFLECTION ON

SKILL DECISION MAKING OF SMA STUDENTS IN ENERGY RENEWABLE MATERIALS

\author{
Maryani \\ Program Studi Pendidikan Fisiika FKIP Universitas Jember \\ Jember, 68121, Indonesia \\ drs.maryani@ymail.com
}

\begin{abstract}
Abstrak
Penelitian ini bertujuan untuk pengaruh LKS dengan strategi inkuiri terbimbing berbasis penalaran terhadap keterampilan pengambilan keputusan siswa SMA pada materi energi terbarukan. Penelitian ini merujuk pada model pengembangan Kemp. Subjek penelitian adalah siswa kelas XII. Pengumpulan data dilakukan dengan teknik pengamatan, dokumentasi, angket, dan wawancara. Analisis data dilakukan dengan menggunakan analiss N-Gain. Hasil penelitian menunjukkan bahwa LKS dengan strategi inkuiri terbimbing berbasis penalaran dapat meningkatkan keterampilan pengambilan keputusan siswa SMA pada materi energi terbarukan.
\end{abstract}

Kata Kunci: LKS, strategi inkuiri terbimbing berbasis penalaran, dan keterampilan pengambilan keputusan

\begin{abstract}
This study aims for the influence of LKS with guided inquiry based strategy on the skills of high school students' decision making on renewable energy materials. This research refers to the Kemp development model. The subjects of the study were the students of class XII. The data were collected by observation, documentation, questionnaire, and interview. Data analysis was performed using $N$ Gain analys. The results showed that LKS with guided inquiry based strategy can improve the decision skill of high school students on renewable energy materials.
\end{abstract}

Key words: LKS, reasoned guided inquiry strategy, and decision-making skill 


\section{Pendahuluan}

Masalah yang dihadapi dalam dunia pendidikan di Indonesia salah satu diantaranya adalah lemahnya proses pembelajaran (Sudarman, 2007). Oleh karena itu pembelajaran harus dikemas sedemikian rupa sehingga dapat menghasilkan lulusan yang kompetitif dan inovatif. Pembelajaran dikatakan bermutu jika aspek kognitif, psikomotorik, dan afektif sudah memenuhi standar yang ditetapkan dalam tujuan pendidikan dan hasil dari pendidikan tersebut sudah sesuai dengan harapan masyarakat dan lingkungan. Pentingnya pembelajaran yang bermutu ini dikarenakan pembelajar (siswa) merupakan generasi penerus bangsa sehingga harus mempunyai keterampilan-keterampilan penunjang yang dapat menjadi pendukung kesuksesannya. Keterampilan yang dimaksud menurut Triling dan Fadel (dalam Murti dan Madya, 2013) yaitu yaitu (1) keterampilan hidup dan berkarir; (2) keterampilan teknologi dan media informasi; (3) keterampilan belajar dan berinovasi. Dari ketiga keterampilan tersebut, keterampilan belajar dan berinovasi yang didalamnya termasuk keterampilan bernalar sangat ideal untuk dikembangkan dijenjang pendidikan Sekolah Menengah Atas (SMA). Hal ini sebagaimana tertuang di dalam Permendikbud No. 60 Tahun 2013 tentang struktur kurikulum SMA/MA yang menyatakan bahwa kompetensi yang harus dicapai oleh siswa SMA/MA dalam pembelajaran fisika diantaranya kemampuan bernalar.

Kemampuan bernalar (reasoning ability) sangat dibutuhkan oleh siswa untuk menentukan suatu keputusan (Gunawan, 2013). Keterampilanketerampilan tersebut menjadi sangat penting karena berperan terhadap diri siswa dalam menggabungkan berbagai informasi untuk menghasilkan solusi yang inovatif. Hal ini diperkuat dari pendapat Sternberg (2008) yang menyatakan bahwa pengambilan keputusan adalah penggunaan penalaran untuk menyeleksi satu pilihan di antara beberapa pilihan. Keterampilan pengambilan keputusan merupakan proses berpikir untuk mengidentifikasi dan memutuskan pilihan dari berbagai pilihan yang ada dengan mengajak siswa berpikir kritis (critical thinking). Keterampilan mengambil keputusan serta kemampuan bernalar menjadi tuntutan pendidikan di Indonesia. Pentingnya kemampuan tersebut untuk dilatihkan pada saat proses pembelajaran sebagaimana Permendikbud No. 64 Tahun 2013 tentang standart isi menyatakan bahwa kemampuan menyelesaikan masalah dan menentukan keputusan merupakan tuntutan pada kompetensi pengetahuan yang harus dikuasai oleh siswa.

Fakta yang ada kemampuan siswa Indonesia dalam mengambil keputusan masih kurang memuaskan. Hasil studi PISA tahun 2012 menunjukkan bahwa siswa Indonesia hanya mampu bernalar secara langsung dan membuat interprestasi berdasarkan hasil penemuan ilmiah dalam menyelesaikan masalah. Akan tetapi belum mampu menggunakan berbagai informasi, penjelasan, dan bukti untuk mengambil keputusan, belum mampu mendemonstrasikan atau menunjukkan kemampuan dalam berpikir dan bernalar secara ilmiah. Selain itu, siswa Indonesia juga belum mampu mengembangkan suatu pernyataan dalam menggunakan fakta dan mengambil keputusan berdasarkan pengetahuan ilmiah (OECD, 2013).

Hasil studi PISA tersebut di atas juga sesuai dengan hasil analisis observasi awal keterampilan pengambilan keputusan siswa dibeberapa Sekolah Menengah Atas di Kabupaten Jember yang menunjukkan bahwa keterampilan tersebut berada dalam kategori kurang baik dengan skor rata-rata 31. Selain itu dalam menjawab 
soal, siswa lebih menekankan hasil akhir dengan tanpa melalui tahapan proses bernalar yang benar. Selanjutnya dari hasil observasi selama pembelajaran berlangsung ternyata: 1) kurang adanya variasi dalam penggunaan model pembelajaran sehingga mengakibatkan kejenuhan pada siswa; 3) kurang tersedianya alat bantu belajar yang mendukung siswa untuk mendapatkan sendiri pengetahuannya.

Rendahnya keterampilan mengambil keputusan diindikasikan karena belum adanya perangkat pembelajaran yang berbasis pada inkuiri sebagaimana yang disarankan Permendikbud No. 65 Tahun 2013. Selain itu, fisika menjelaskan gejala alam yang cenderung bersifat verbal sehingga pengunaan bahasa yang kurang tepat dalam membelajarkan siswa dapat menimbulkan bias dalam memahami konsep fisikanya sendiri. Sehubungan dengan beberapa permasalahan yang berkaitan dengan hasil observasi pembelajaran di atas, maka diperlukan upaya-upaya kreatif dan inovatif yang mencakup metode inovasi pengelolaan kelas atau pembelajaran dengan penggunaan alat-alat inovatif tertentu termasuk penggunaan LKS (Lembar Kerja Siswa) berbasis penemuan atau inkuiri. LKS meruapakan panduan siswa yang digunakan untuk melakukan kegiatan penyelidikan dan pemecahan masalah (Trianto, 2008). LKS biasanya berupa petunjuk atau langkah untuk menyelesaikan suatu tugas. Suatu tugas yang diperintahkan dalam lembar kerja tersebut harus jelas kompetensi dasar yang akan dicapainya (Depdiknas, 2004). Penggunaan LKS dalam proses pembelajaran mempunyai beberapa tujuan, yaitu untuk menuntun siswa dalam menyelesaikan permasalahan serta mempertimbangkan proses berpikir yang akan ditumbuhkan pada diri siswa (Azhar, 1993).
LKS yang telah disusun tersebut perlu didasarkan pada suatu strategi belajar. Adapun strategi tersebut menggunakan strategi inkuiri terbimbing berbasis penalaran. Pentingnya penggunaan strategi inkuiri/ penemuan tersebut didasari dari Permendikbud No. 65 Tahun 2013 tentang standar proses pendidikan dasar dan menengah yang menyatakan bahwa keterampilan diperoleh melalui aktivitas mengamati, menanya, mencoba, menalar, menyaji, dan mencipta. Untuk memperkuat pendekatan ilmiah (scientific), tematik terpadu (tematik antarmata pelajaran), dan tematik (dalam suatu mata pelajaran) perlu diterapkan pembelajaran berbasis penyingkapan atau penelitian (discovery/inquiry learning).

Esensi inkuiri merupakan suatu proses penemuan ilmiah, sedangkan pengambilan keputusan harus didasarkan pada sejumlah data yang diperoleh melalui proses penemuan secara ilmiah. Strategi inkuiri terbimbing memberikan peluang, ruang, dan dorongan untuk mengembangkan kemampuan bernalar siswa. Dengan kata lain, strategi inkuiri terbimbing ini merupakan suatu rangkaian kegiatan belajar yang melibatkan secara maksimal seluruh kemampuan siswa untuk mencari dan menyelidiki secara sistematis, kritis, logis, dan analitis sehingga mereka dapat menemukan sendiri pengetahuannya dengan penuh percaya diri (Gulo dalam Trianto, 2007). Pengembangan LKS dengan strategi inkuiri terbimbing berbasis penalaran untuk meningkatkan keterampilan pengambilan keputusan memberi kesempatan kepada siswa untuk merumuskan masalah melalui pertanyaan, membuat hipotesis, merancang dan melakukan percobaan, mengumpulkan data, dan menganalisis data. Selain itu, pada tahap penutupnya memberi kesempatan kepada siswa untuk membuat kesimpulan serta meminta siswa mengerjakan permasalahan. Adapun dipilihnya penalaran selain sesuai dengan 
Permendikbud No. 65 Tahun 2013 tentang standar proses pendidikan dasar dan menengah juga diperkuat oleh hasil penelitian Chun (2010) yang menyatakan bahwa siswa yang memiliki kemampuan bernalar yang baik akan memiliki kemampuan memecahkan masalah yang baik. Selanjutnya proses dalam menyelesaikan masalah mampu membelajarkan kemampuan mengambil keputusan (Frederiksen, 1984). Ketika siswa terlibat dalam menyelesaikan suatu masalah berarti siswa tersebut telah mampu mengambil keputusan serta menyusun kesimpulan dari masalah pada suatu topik tertentu (Kim dkk, 2014).

Beberapa hasil penelitian dengan menggunakan model inkuiri terbimbing menunjukkan hasil yang positif sebagaimana penelitian yang dilakukan oleh Amien, dkk (2012) yang menyimpulkan bahwa pembelajaran dengan model inkuiri terbimbing dapat meningkatkan aktivitas siswa pada aktivitas percobaan dan pengamatan, respons siswa positif dan pemahaman konsep siswa, tetapi dalam penelitian ini tidak secara langsung melihat kemampuan bernalar siswa. Penelitian yang lain juga dilakukan oleh Jonassen dan Serrano (2002) dengan hasil bahwa kemampuan bernalar diperlukan untuk menganalisis, mengorganisasi dan menyajikan suatu fenomena untuk menyelesaikan masalah sehingga pada akhirnya berpengaruh dalam pengambilan keputusan.

Penelitian ini bertujuan untuk pengaruh LKS dengan strategi inkuiri terbimbing berbasis penalaran terhadap keterampilan pengambilan keputusan siswa SMA pada materi energi terbarukan.

\section{Metode Penelitian}

Penelitian ini merupakan penelitian pengembangan (developmental research) dengan rancangan pengembangan dan keseluruhan pada penelitian ini mengikuti tahapan model Kemp, sedangkan rancangan penerapan hasil pengembangan perangkat pembelajarannya menggunakan one group pretest-posttest design pada siswa kelas XII IPA 1, XII IPA 2, dan XII 3 SMA. Pengumpulan data dilakukan dengan teknik pengamatan, dokumentasi, angket, dan wawancara. Sedangkan analisis data dilakukan dengan menggunakan N-Gain.

\section{Hasil Penelitian dan Pembahasan}

Pengukuran hasil tes keterampilan pengambilan keputusan dilakukan terhadap 3 subyek penelitian. Hasil analisis pada subyek penelitian 1 secara ringkas dapat dlihat pada Gambar 1.

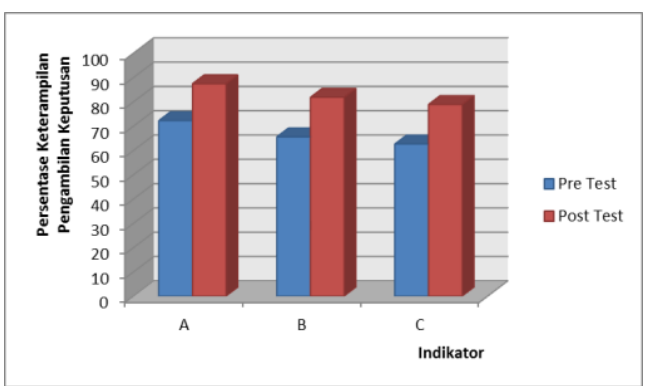

\section{Gambar 1 Hasil Analisis Keterampilan Pengambilan Keputusan pada Subyek Penelitian 1}

Berdasarkan Gambar 1 di atas dapat diketahui bahwa indikator A mewakili membuat pertanyaan apa yang diputuskan pada pre test dan post test masing-masing berskor 72,22 dan 92,96, indikator B mewakili mengumpulkan informasi pada pre test dan post test masing-masing berskor 65,56 dan 87,41, indikator $\mathrm{C}$ mewakili menentukan dan menganalis pilihan-pilihan pada pre test dan post test masing-masing berskor 69,17 dan 83,33 . Untuk mengetahui pengaruh pengembangan LKS dengan strategi inkuiri terbimbing berbasis penalaran terhadap keterampilan pengambilan keputusan maka digunakan analisis $\mathrm{N}$ Gain dengan hasil pada subyek penelitian 
1 ada $37 \%$ berkriteria tinggi, $57 \%$ berkriteria sedang, dan $7 \%$ berkriteria rendah dan secara umum dapat dilihat pada Gambar 2.

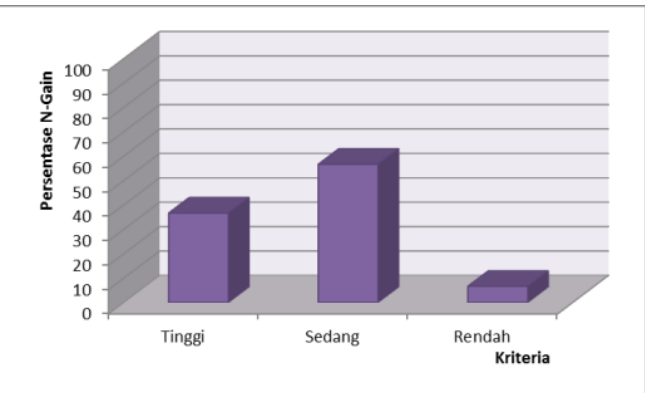

Gambar 2 Hasil Analisis N-Gain pada Subyek Penelitian 1

Hasil analisis tes keterampilan pengambilan keputusan subyek penelitian 2 secara ringkas dapat dlihat pada Gambar 3.

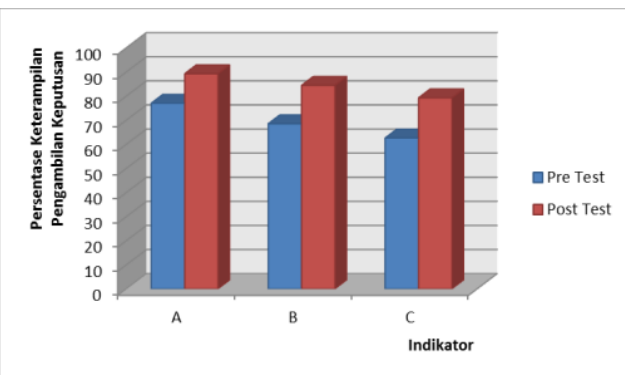

Gambar 3 Hasil Analisis Keterampilan Pengambilan Keputusan pada Subyek Penelitian 2

Berdasarkan Gambar 3 di atas dapat diketahui bahwa masing-masing indikator $\mathrm{A}$, indikator $\mathrm{B}$, dan indikator $\mathrm{C}$ pada pre test dan post test secara berurutan berskor 77,04 dan 93,33, 68,52 dan 88,89, serta 62,59 dan 83,70. Untuk mengetahui peningkatan keterampilan pengambilan keputusan setelah mengikuti pembelajaran menggunakan hasil pengembangan LKS dengan strategi inkuiri terbimbing berbasis penalaran terhadap keterampilan pengambilan keputusan, maka digunakan analisis N-Gain dengan hasil pada persentase siswa yang berkriteria tinggi 40 $\%$, berkriteria sedang $57 \%$, dan berkriteria rendah $33 \%$ dan secara lengkap dapat dilihat pada Gambar 4.

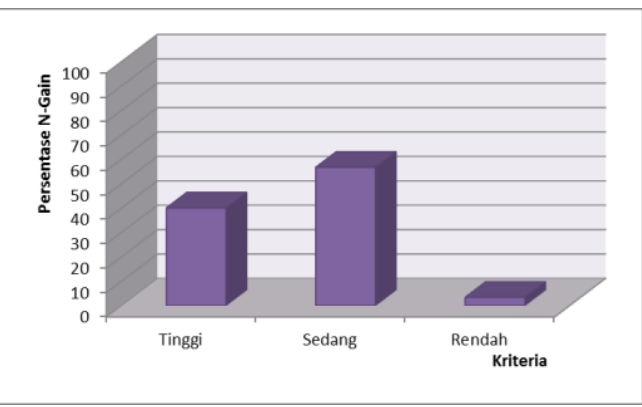

Gambar 4 Hasil Analisis N-Gain pada Subyek Penelitian 2

Berdasarkan analisis hasil tes keterampilan pengambilan keputusan pada kelompok penelitian 3 didapatkan data bahwa bahwa indikator A pada pre test dan post test masing-masing berskor 77,78 dan 92,96 , indikator B pada pre test dan post test masing-masing berskor 69,26 dan 87,41 , indikator $C$ pada pre test dan post test masing-masing berskor 63,33 dan 81,78, indikator D mewakili membuat kesimpulan pada pre test dan post test masing-masing berskor 66,94 dan 80,00. Hasil analisis keterampilan pengambilan keputusan pada kelompok penelitian 3 dapat dilihat pada Gambar 5.

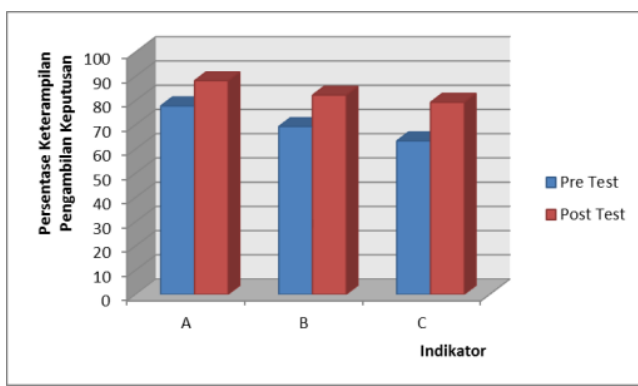

\section{Gambar 5 Hasil Analisis Keterampilan Pengambilan Keputusan pada Subyek Penelitian 3}

Untuk mengetahui peningkatan keterampilan pengambilan keputusan setelah mengikuti pembelajaran dengan menggunakan hasil pengembangan LKS dengan strategi inkuiri terbimbing berbasis penalaran terhadap maka digunakan 
analisis $\mathrm{N}$-Gain dengan hasil pada subyek penelitian 3 ada $20 \%$ berkriteria tinggi, 73 $\%$ berkriteria sedang, dan $7 \%$ berkriteria rendah dan secara umum dapat dilihat pada Gambar 6.

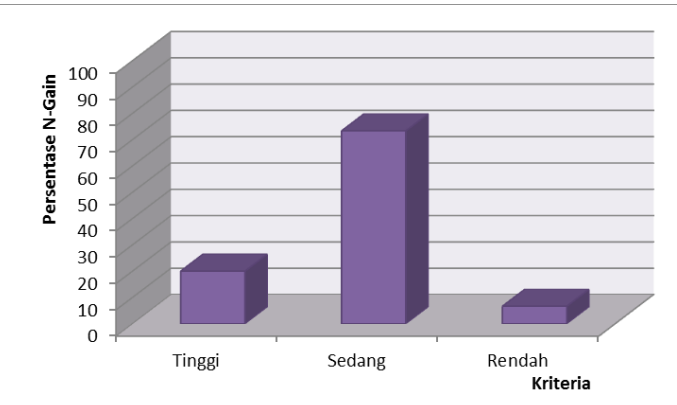

\section{Gambar 6 Hasil Analisis N-Gain pada Subyek Penelitian 3}

Penerapan LKS dengan strategi inkuiri terbimbing berbasis penalaran dapat meningkatkan keterampilan pengambilan keputusan siswa. Hal ini dibuktikan dari hasil analisis data keterampilan pengambilan keputusan siswa antara sebelum dan sesudah implementasi LKS tersebut. Pre test digunakan untuk mengetahui keterampilan pengambilan keputusan awal siswa sebelum pembelajaran berlangsung, sedangkan post test digunakan untuk mengetahui keterampilan pengambilan keputusan siswa setelah implementasi dengan menggunakan LKS yang telah dikembangkan. Adapun indikator keterampilan pengambilan keputusan yang digunakan pada penelitian adalah (1) membuat pertanyaan apa yang diputuskan melalui pengenalan masalah dalam bentuk tertulis berupa pertanyaan yang diketahui dari apa yang ditanyakan pada soal dengan tepat; (2) mengumpulkan informasi yaitu dengan menuliskan informasi-informasi yang relevan dari teori, hukum, postulat, konsep dengan tepat; dan (3) menentukan dan menganalis pilihan-pilihan dengan menentukan pilihan dari sumber informasi yang sudah terkumpul dengan benar dan dapat menjelaskan alasan atas pilihan tersebut dengan tepat.

$\mathrm{Ke}$ tiga indikator tersebut kemudian dianalisis ketuntasannya dengan hasil subyek penelitian 1, subyek penelitian 2, dan subyek penelitian 3 masing-masing ditunjukkan Gambar 5.1, Gambar 5.3, dan Gambar 5.5. Berdasarkan ketiga gambar tersebut dapat diketahui bahwa secara rata-rata ada peningkatan keterampilan pengambilan keputusan siswa sebelum (yang ditunjukkan grafik pada pretest) dan sesudah penerapan LKS dengan strategi inkuiri terbimbing berbasis penalaran (yang ditunjukkan grafik pada posttest).

Untuk mengetahui apakah ada peningkatan keterampilan pengambilan keputusan sebelum dan sesudah penerapan LKS, maka digunakan analisis N-Gain sebagaimana hasil analisisnya dapat dilihat pada Gambar 5.2, 5.4, dan 5.6. Peningkatan hasil tes keterampilan pengambilan keputusan dikarenakan selama pembelajaran berlangsung LKS memberikan suatu dampak terhadap proses pembelajaran. Sebagaimana pendapat Darmodjo dan Kaligis (1992) yang menyatakan bahwa LKS merupakan sarana pembelajaran yang dapat digunakan guru dalam meningkatkan keterlibatan atau aktivitas siswa dalam proses pembelajaran dan memberikan manfaat yaitu: (1) memudahkan guru dalam mengelola pembelajaran; (2) membantu guru mengarahkan siswanya untuk dapat menemukan konsep-konsep baik secara mandiri maupun berkelompok; (3) dapat digunakan untuk mengembangkan keterampilan proses, mengembangkan sikap ilmiah serta membangkitkan minat siswa terhadap alam sekitarnya; (4) memudahkan guru memantau keberhasilan siswa untuk mencapai tujuan pembelajaran. Selain itu pengembangan LKS dengan menggunakan strategi inkuiri terbimbing berbasis penalaran juga memberikan dampak terhadap 
meningkatnya keterampilan pengambilan keputusan siswa.

Menurut Victor dan Kellough (dalam Jacobsen, 2009) inkuiri yang memiliki makna penelitian merupakan suatu proses dalam menjawab pertanyaanpertanyaan dan memecahkan masalahmasalah berdasarkan pengujian logis atas fakta-fakta dan observasi-observasi. "strategi-strategi penelitian menggunakan proses-proses ini untuk mengajarkan konten dan untuk membantu siswa berpikir secara analitis", sedangkan penalaran merupakan kegiatan, proses atau aktivitas berpikir untuk mendapatkan suatu kesimpulan atau membuat suatu pernyataan baru dengan berdasarkan kepada beberapa pernyataan yang diketahui kebenarannya ataupun yang dianggap kebenarannya ataupun yang diasumsikan kebenarannya (Copi dalam shadiq,2007).

\section{Daftar Pustaka}

Borich, G. 1994. Observation Skill for Effective Teaching. New York: Mac Millan Publishing Company.

BSNP. 2010. ParadigmaPendidikan Nasional Abad XXI. [Online]. Tersedia: http://www.bsnpindonesia.org/id/wpcontent/uploads/2012/04/Laporan -BSNP-2010.pdf diakses pada tanggal 11 Juni 2017 Pukul 13.00 WIB.

Depdiknas. 2004. Kerangka Dasar Kurikulum 2004. Jakarta.

Depdiknas. 2005. Pengembangan

Panduan

Pembelajaran Model

Kompetensi. Jakarta: Direktorat PPTK dan KPT Dirjen Dikti.

Dimyati dan Mudjiono. 2002. Belajar dan Pembelajaran. Jakarta: Rineka Cipta.
Ennis, R. H. 2011. "The Nature of Critical Thinking: An Outline of Critical Thinking Abilities". Last Revise Paper Presented at The Sixth International Conference on Thinking at MIT, Cambridge.

Fisher, Alec. 2009. Berpikir Kritis: Sebuah Pengantar. Jakarta: Erlangga.

Hake, R. R. (1999). Analyzing Change/Gain Scores. USA: Departmentof Physics, Indiana University.

Hamalik, Umar. 2005. Kurikulum dan Pembelajaran. Jakarta : Bumi Aksara.

Liliasari. 2009. Berpikir kritis dalam Pembelajaran Sains Kimia Menuju Profesionalitas Guru. Program Studi Pendidikan IPA. Sekolah Pascasarjana UPI.

Mariana, I. M.A dan Praginda, W. 2009. Hakikat IPA dan Pendidikan IPA untuk guru SD. Jakarta: Pusat Pengembangan dan Pemberdayaan Pendidik dan Tenaga Kependidikan IPA.

Miarso, Yusufhadi. 2007. Menyemai Benih Teknologi Pendidikan. Jakarta: Kencana.

OECD. 2014. PISA 2012 Result : What Student Know and Can Do volume 1. Canada : OECD.

Balitbang.2011. Hasil Survei TIMSS :2011. Trends Internasional Mathematics and Scince Study. US: TIMSS and PIRLS International Study Center. 
100 Jurnal Pembelajaran Fisika, Vol. 7 No. 1, Maret 2018, hal 93-99 